\title{
INSIDE AN ENGLISH LANGUAGE TEACHER EDUCATION PROGRAM IN VIETNAM: STUDENTS' MOTIVATIONS FOR TEACHING AND THEIR INTENTIONS TO TEACH
}

\author{
Tran Thi Hong Duyen, Cao Thuy Hong* \\ Faculty of English Language Teacher Education, \\ VNU University of Languages and International Studies, \\ Pham Van Dong, Cau Giay, Hanoi, Vietnam
}

Received 05 January 2020

Revised 11 April 2020; Accepted 28 May 2020

\begin{abstract}
Recent years have witnessed a decrease in both the number and quality of students enrolling in English Language Teacher Education (ELTE) programs. Those ELTE graduates also tend to pursue careers other than teaching. Given the great demand for English language learning at the moment, such low motivation for teaching is undesirable. This study was thus conducted to investigate motivations for teaching of senior students at a language teacher education institution in Vietnam as well as the correlations between these motivating factors and their intentions to teach. Data was collected from 114 senior students using questionnaires, and analyzed using SPSS (version 20.0). Findings from the study suggested that (a) participants displayed a positive prospect of pursuing teaching career; (b) prior teaching and learning experience, making social contribution, and shaping future of children/adolescents were the most influential factors while fallback career, job transferability, and time for family were the least endorsed ones; (c) although teaching is perceived to be part of a respected profession that requires expert knowledge and emotional devotion, teachers are generally underpaid; (d) significant relations were observed between intrinsic career value, satisfaction with choice, social utility values, perceived ability, and prior teaching and learning experience and intentions to teach.
\end{abstract}

Keywords: motivation for teaching, intentions to teach, FIT-Choice scale, Vietnamese settings, prospective teachers

\section{Context of the study}

Vietnam is usually considered to be part of the Confucian Heritage culture, together with other Asian countries like China, Japan, Korea (Nguyen, Jin, \& Gross, 2013). As a result, Vietnamese people tend to show a high respect for learning and believe that education is the path to success (Hays, 2008). Teaching is usually considered a prestigious career, and the position of teachers has always been held high in Vietnamese society. In the old Vietnamese society, the hierarchy of "king, teacher, father" (with teachers being placed above fathers and only below the

\footnotetext{
Corresponding author: Tel.: 84-936693110

Email: hongcao3110@gmail.com
}

king; Dinh, 2012) was typically endorsed, which highlighted people's deep respect for the teaching profession. Other historical and folklore references of the Vietnamese also stressed the importance of the teaching career as stated in the following sentences:

If one wants to cross the water, build a bridge. If one wants his child to be educated, respect the teacher.

Rice father, clothes mother, knowledge teacher ${ }^{1}$.

Teaching is the most noble profession among other noble professions.

\footnotetext{
Vietnamese original: Corm cha áo me chũ thầy, which basically means Father gives you rice, mother gives you clothes, and teacher gives you knowledge, or You are indebted to your father for rice, your mother for clothes, and your teacher for knowledge.
} 
(Phan \& Phan, 2006, p.5)

In short, Vietnamese culture promotes teaching career as being the noblest profession and teachers' merit in educating people being as important as parental efforts in children's upbringing.

However, students' perceptions of the teaching career have changed drastically in recent years. This change can be observed firstly through the decrease in the number of high school students enrolling in teacher education courses. The statistics provided by Vietnam's Ministry of Education and Training (MOET, 2018) indicated that the number of students applying for teacher training program in 2018 fell 29\% compared with that in 2017 (Nguyen, 2018). Additionally, many prospective teachers are showing little interest in entering teaching career after graduation. According to Vietnam's Ministry of Finance (MOF, 2017 as cited in Nguyen, 2017), many graduates of Teacher Education program choose to follow careers other than teaching. Several reasons are believed to hold accountable for this trend, namely the low salary, the poor career prospect as well as the pressure from huge workload and students' parents (Nguyen, 2019).

\section{Literature review}

\section{Factors affecting teaching choice}

Exploring factors that influence individuals' career choices has long been a common topic among vocational and behavioural psychologists. Numerous research studies have been carried out in the search for factors that influence the choice of teaching, the majority of which based their interpretations on the traditional conceptualizations of teaching motivations, namely intrinsic, extrinsic, and altruistic motivation (Kyriacou \& Coulhard, 2000). According to Kyriacou \& Coulhard (2000), intrinsic motivation concerns the teaching activity itself (e.g., personal interest, intellectual fulfilment), while extrinsic motivation deals with the non-latent aspects of teaching job (e.g., salary, lengthy holidays), and altruistic motivation is related to the desire to make social contribution. However, there exist a couple of issues with this classification.

- Firstly, these three constructs seemed to have been understood differently in different contexts. For example, "desire to work with children" is frequently included in intrinsic motivation; however, it also appeared as a form of altruistic motivation in Yong (1995). Financial burden was included in Low, Lim, Ch'ng \& Goh (2011) as an extrinsic motivation leading to teaching career choice although this was not previously mentioned in Kyriacou and Coulhard's (2000) work.

- Secondly, factors other than intrinsic, extrinsic, and altruistic motivation have also been suggested in different contexts. For instance, Thomas, Turner, and Nietfeld (2011) identified six motivational groups: intrinsic values, job benefits, meaningful relationship, altruistic views, ability, and opportunities, which do not exactly coincide with the three categories of motivation previously mentioned.

According to Watt and Richardson (2007), the lack of an agreed analytical and theoretical framework to define the constitution of intrinsic, extrinsic, and altruistic motivations might have led to the inconsistent definition and overlapping categorizations. The Factor Influencing Teaching Choice (FIT-Choice) framework was thus developed by Watt and Richardson (2006) to assess the primary motivations of teachers to teach, and was demonstrated to be 
psychometrically sound (Watt \& Richardson, 2007). The framework thus was selected to guide the study since it proved to minimize the problems observed in previous studies using traditional conceptualizations of teaching motivation. In the part that follows, Watt and Richardson's (2007) framework is described in more details to lay the foundation for the whole study.

\section{Watt and Richardson's FIT-Choice framework}

The Factors Influencing Teaching Choice or FIT-Choice framework (Watt \& Richardson, 2006) was largely based on the Expectancy-value theory, which is one of the major frameworks for achievement motivation. The Expectancy-value theory was developed to explain the impacts of the nature of expectancy and value constructs on individual's choice and performance (Wigfield \& Eccles, 2000). This theory highlighted expectancies of success and task values as the determining factors and considered socialization and individuals' perceptions of their past experiences as distal influences. According to this theory, expectancy of success was constructed by beliefs of three categories, namely goals, self-concept, and task difficulty (see Figure 1). Value could be categorized into intrinsic value - the enjoyment one derives from doing a particular task, utility value - the usefulness of task to an individual, attainment value - the importance of doing well on a task, and cost - the sacrifice one makes in doing the task.

In a similar vein, the FIT-Choice framework was guided by self-perceptions of ability, value and task difficulty. The intrinsic motivations, altruistic motivations and extrinsic motivations that have been emphasized in the past relevant literature are also covered in this model. In the FIT-Choice model (see Figure 2), altruistic motivations were referred to as personal utility value, which includes the job security, time for family, and job transferability. Social utility value consisted of four components: shaping the future of children/adolescents, enhancing social equity, making social contributions, and working with children/adolescents. Intrinsic value in this scale measured the interest and desire to follow teaching career. Four motivational factors that were added in FIT-Choice framework are prior teaching and learning experience, social influences, perceived teaching abilities, and 'fallback' career reflecting the fact that teaching is people's last resort rather than the desired career. The measured perceptions include task demand (expert career, high demand) and task return (social status, salary), social dissuasion experiences, and satisfaction with teaching choice.

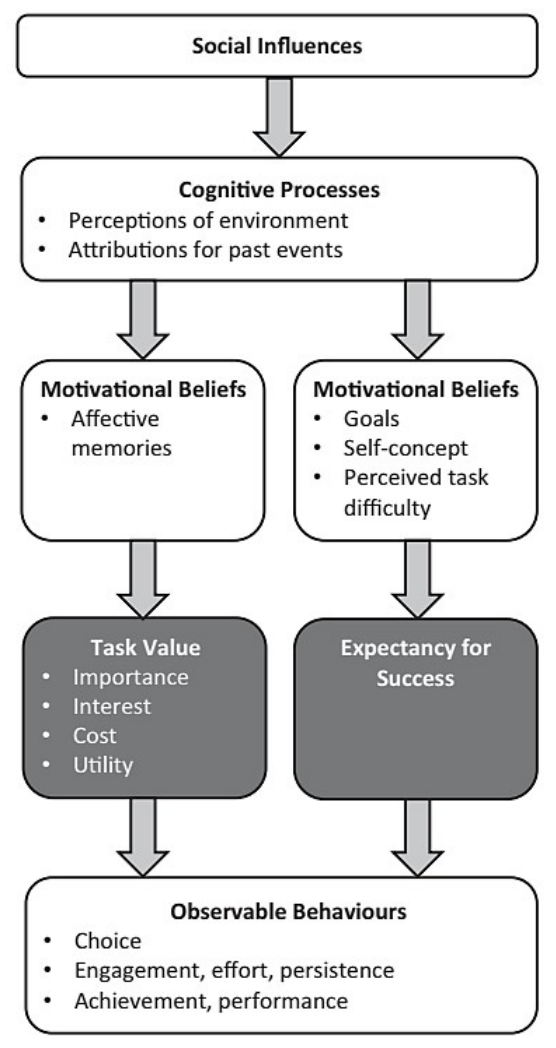

Figure 1. A simplified version of Wigfield and Eccles's expectancy-value theory (Cook \& Artino, 2016) 


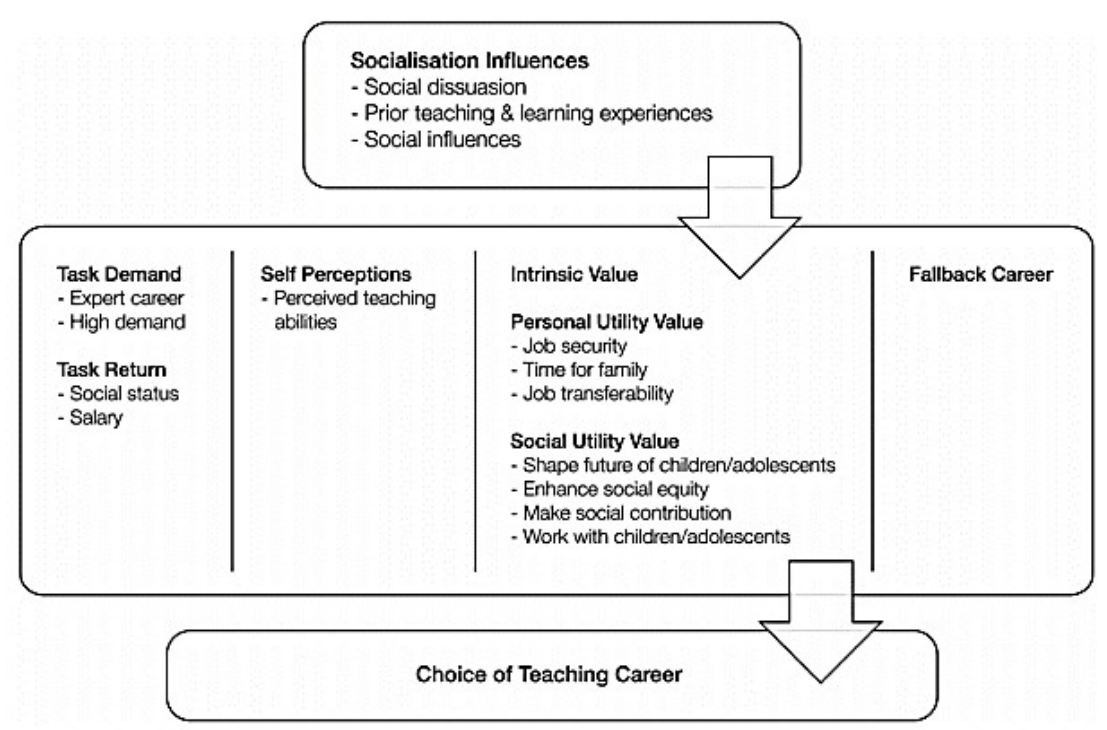

Figure 2. FIT-Choice empirically validated theoretical model (Watt \& Richardson, 2012)

The FIT-Choice framework has been carried out globally to investigate motivations for teaching in different countries such as Turkey (Kılınç, Watt \& Richardson, 2012), China (Lin, Shi, Wang, Zhang \& Hui, 2012), the Netherlands (Fokkens-Bruinsma \& Canrinus, 2012), Croatia (Jugović, Marušic, Ivanec, \& Vidovic, 2012), German (König \& Rothland, 2012), Sweden (Berger \& D'Ascoli, 2012). Across different contexts, research findings appeared to suggest that social utility value such as shape future of children/ adolescents and make social contribution were especially important to a teaching choice (Watt \& Richardson, 2012). Besides, personal utility was also highly rated, which was understandable and indicated the basic needs of teachers in modern society.

Besides these similarities, Watt and Richardson (2012) also noted note-worthy differences in teaching motivation across different settings. First of all, perceived abilities and intrinsic value were considered highly important in the US, Dutch, Croatian, German, Swiss and Australian contexts whereas in
China and Turkey, job security was prioritized. When it comes to desire to work with children/ adolescents, except for the Chinese setting, participants in other countries shared the same belief that this factor was central in one's decision to become a teacher. As for social influences, a study of Dutch pre-service teachers' motivations (Fokkens-Bruinsma \& Canrinus, 2012) was the only case in which the teacher choice was considerably influenced by social factors. Regarding the perceptions, apart from the Chinese context, in which task demand and task return were rated low, results of both factors from other countries indicated high task demand and low task return. From the utilization of FIT-Choice framework in various countries, it could be speculated that different cultural and socioeconomic backgrounds might have implications for individual differences in motivations to teach.

\section{Rationale for the study}

In the context of Vietnam, individuals wishing to join the job market are required 
to possess not only professional competence but also foreign language ability, especially English. The Project "Teaching and Learning Foreign Languages in the National Education System, Period 2008 - 2020" (Project 2020) was thus launched with the purpose of improving the competitiveness of the Vietnamese workforce in the international labour market (through strengthening their foreign language ability; Le \& Nguyen, 2017). It has also been well-recognized that to achieve the stated aims, teacher training should be a central and prioritized task as it provides the qualified English language teachers needed for the project (MOET, 2018; as cited in Nguyen, 2018). In fact, a substantial amount of the project budget has been allocated to the training of English language teachers at different levels, including undergraduate level (MOF, 2018).

However, the state of English language teacher education is no better than that of the general situation of teacher education in Vietnam. Thousands of students enroll in English language teacher education programs every year (probably because it is free; Nguyen, 2017). However, many of the graduates from EFL teacher education programs have expressed lack of interest in teaching and decided to pursue other career paths after graduation. This is a waste of national investment and has led to a shortage of more than 5,600 English language teachers from different educational strands (MOET, 2018; as cited in Nguyen, 2018).

Our review of the existing literature above has suggested that several attempts have been made to discover the motivations to teach in different settings. However, until recently, studies that have been conducted on the motivational factors that influence teaching choice in the Vietnamese context are almost non-existent (Pham, 2012); those that are applicable to the Vietnamese context are also very limited. With the typical features of Vietnamese labour market (a socialist- oriented market economy) and the advantages in terms of language that English-majored students have in the Vietnamese labour market (i.e., better job opportunities), it is speculated that factors that worked in other contexts may not necessarily be applicable to the Vietnamese situation. This study thus aimed to investigate the factors influencing teaching choice of senior students majoring in English language teacher education in the Vietnamese context with the belief that thorough understanding of pre-service teachers' career intention and factors influencing their choices is crucial to better promote their teaching motivations, which consequently would help to increase the number of students following teaching career path.

\section{Research questions}

This research aims to investigate (1) intentions to pursue teaching career of seniors at an English Language Teacher Education institution in Vietnam, (2) factors that influence their choices of a teaching career, and (3) the correlations between factors influencing teaching choice and intention to teach. Specifically, the research aims to answer the following research questions:

1. To what extent do participants in the current study wish to pursue teaching career?

2. What are the factors that influence their choice of teaching career?

3. What are the correlations between influencing factors and students' intention to teach?

\section{Research design}

The study was designed as quantitative research with the employment of a questionnaire to gather data.

\section{Participants}


Total random sampling technique was adopted to select participants in the current study. In other words, all (196) senior students majoring in English Language Teacher Education at a teacher training institution in Hanoi were invited to participate in the study. This method of collecting information from the total population was expected to give deeper insights into the target population than what partial samples would probably be capable of. It allows researchers to create a much more complete picture of the phenomenon and greatly reduces guessing work. It also eliminates the risk of biased sample selection that is often encountered in would-be random study samples.

Participants in the current study were competent in English. Most of them have obtained VSTEP (Vietnamese Standardized Test of English Proficiency) C1 level (equivalent to $\mathrm{C} 1$ in CEFR). They had reasonable knowledge about the subject matters (English language), knowledge about teaching and teaching experiences (through the courses at the university as well as the teaching practicum) and were going to join the labour market in the coming few months. Therefore, it was expected that these students would hold a clearer view of their future career path than freshmen, sophomores, and juniors. Their responses to the questionnaire would be more reliable and valid.

\section{Data collection instrument}

The researchers adapted the Factors Influencing Teaching Choice (FIT-Choice) survey (Watt \& Richardson, 2006) to examine the motivations for teaching among senior students and Jung's (2014) Occupational Intention scale to measure their intentions of becoming teachers. Watt and Richardson's (2006) FIT-Choice survey consisted of 58 items that covered 12 motivation constructs (ability, intrinsic career value, fallback career, job security, time for family, job transferability, shape future of children/adolescents, enhance social equity, make social contribution, work with children/adolescents, prior teaching and learning experiences, and social influences), six perception constructs (expertise, difficulty, social status, salary, and social dissuasion) and one construct about satisfaction with choice. The FIT-Choice survey was validated by recognized experts (Watt \& Richardson, 2007) and scrutinized in diverse settings (Jugović, Marušic, Ivanec, \& Vidovic, 2012; König \& Rothland, 2012; Berger \& D'Ascoli, 2012). Jung's (2014) Occupational Intention was part of a larger scale that was constructed to measure nine constructs that influence an individual's career decision-making process. The scale also underwent a process of development, testing, and refinement over two phases of data collection with the participation of over a thousand students (Jung, 2014).

The two surveys above formed the foundation for the survey used in the current study. The actual survey used in this study consisted of 59 close-ended items and four open-ended items, which were divided into three main parts. In the first part (section A), factual questions in open-ended form were used in order to collect participants' personal information such as name, gender, class, and email address. As for the second part (section B), which concerned senior students' intentions of becoming teachers, five items measuring "Occupational Intention" construct was adapted from Jung's (2014) Occupational Intention scale. Specifically, in this part, participants were requested to indicate their level of agreement to the five items "It is likely that I will pursue teaching career", "I intend to pursue teaching career", "I plan to apply for teaching career", "I have resolved to follow this occupational path" and "I am committed to teaching career". Students' motivations for teaching were measured via two subscales namely "Motivations for teaching" - Section $\mathrm{C}$ - which consists of 38 items; and "Beliefs 
about Teaching and Satisfaction with Choice" - Section D - which consists of 20 items. For three parts $(\mathrm{B}, \mathrm{C}$, and $\mathrm{D})$ of the questionnaire, a seven-point Likert-type scale was utilized (see Appendix 1).

\section{Data collection}

The researchers were able to collect contact information of all senior students at the targeted institution thanks to the help of the class monitors. Due to the schedule of some participants, the researchers had to conduct online questionnaire using Survey Monkey. For the rest of the participants, paperbased questionnaires were used. Prior to the questionnaire distribution, participants were notified of the research topic and research aims as well as encouraged to contact the researchers via email if any further clarifications on the items and the study were needed. Through this two-week data collection process, 194 questionnaires (both online and printed versions) were distributed and 118 completed ones were returned (see Table 1).

Table 1. Number of distributed and returned questionnaires

\begin{tabular}{ccc}
\hline Version & Distributed & Returned \\
\hline Online & 106 & 78 \\
Paper-based & 63 & 40 \\
Total & 194 & 118 \\
\hline
\end{tabular}

Overall response rate $=60.8 \%$

Data collected from questionnaires were then imputed, refined and analysed using the Statistical Package for the Social Sciences (SPSS version 20.0). Specifically, there was (a) preliminary analysis of the data, (b) assessment of scale reliability, (c) calculation of factor scores, and (d) estimation of correlations among factors.

\section{Preliminary data analysis}

Preliminary analysis of the data is a very important step as it provides researchers with important information about the characteristics of their data. In the current study, data were inspected to check for missing data as well as detect any unusual patterns in the dataset. Specifically, the total percentage of missing values was calculated to be approximately $2.04 \%$; the number of cases with incomplete response (with at least one missing value) was 6 out of 118 , which accounted for $5.08 \%$. An inspection of missing data by individual cases revealed that of the 118 returned surveys, 112 participants $(94.9 \%)$ returned fully completed questionnaires, while 6 questionnaires (5.1\%) had at least one missing item.

Closer observation of missing data suggested the exclusion of two cases (ID 45 and ID 116) from the dataset, because more than half of the items in their responses were not completed. Another two cases (ID 25 and ID 62) were also excluded from the dataset because although the percentage of missing values in each response did not exceed $50 \%$, the items missing were deemed indispensable as they all belonged to constructs of Beliefs about teaching and Satisfaction with choice. In the end, data from 114 respondents were retained for analysis; of these, $85.1 \%$ of the participants were female and $14.9 \%$ were male. Their ages ranged from 22 to 24 years old $($ Mean $=22.05 ; \mathrm{SD}=0.26)$.

\section{Assessment of scale reliability}

According to George and Marley (2003, as cited in Gliem \& Gliem, 2003), scale reliability is considered acceptable if the Cronbach's alpha value is higher than .70 and unacceptable if the value falls under .50. As the Cronbach's alpha $(\alpha)$ of 19 subscales comprised this full measurement ranged from .513 for "Fallback career" to .959 for "Occupational Intention" subscale (see Table 2), a conclusion was reached that each factor had a fair to good level of reliability. 
Table 2. Subscales Cronbach's alpha reliabilities $(\alpha)$

\begin{tabular}{lll}
\hline \multicolumn{1}{c}{ Sub-scale } & \multicolumn{1}{c}{ Items } & Cronbach's $\boldsymbol{\alpha}$ \\
\hline Occupational intention & B1, B2, B3, B4, B5 & .959 \\
Ability & C5, C17, C35 & .830 \\
Intrinsic career value & C1, C7, C11 & .872 \\
Fallback career & C10, C29, C37 & .513 \\
Job security & C13, C 23, C32 & .778 \\
Time for family & C2, C4, C14, C16, C24 & .810 \\
Job transferability & C8, C19, C36 & .727 \\
Shape future of children/adolescents & C9, C20, C25 & .840 \\
Enhance social equity & C26, C30, C38 & .750 \\
Make social contribution & C6, C18, C28 & .811 \\
Work with children/adolescents & C12, C22, C31 & .903 \\
Prior teaching and learning experiences & C15, C27, C33 & .778 \\
Social influences & C3, C21, C34 & .698 \\
Expert career & D9, D13, D14 & .788 \\
High demand & D2, D6, D10 & .594 \\
Social status & D4, D7, D11 & .673 \\
Teacher morale & D5, D8, D12 & .591 \\
Salary & D1, D3 & .782 \\
Social dissuasion & D16, D18, D20 & .601 \\
Satisfaction with choice & D15, D17, D19 & .798 \\
\hline
\end{tabular}

\section{Research findings}

\section{Intentions of becoming teachers}

Concerning their intentions of becoming teachers, participants in the current study generally showed a marked tendency towards pursuing a teaching career (see Table 3 ). Among the five options, the likelihood to pursue teaching career was the highest rated $(\mathrm{M}=5.39$,
$\mathrm{SD}=1.46)$, followed by participants' planning to apply for this job $(\mathrm{M}=5.31, \mathrm{SD}=1.63)$ and their intending to follow teaching career $(\mathrm{M}=$ $5.24, \mathrm{SD}=1.60)$. Although the other two items concerning participants' commitment toward teaching job $(\mathrm{M}=4.59, \mathrm{SD}=1.67)$ and their resolution to follow this career path $(\mathrm{M}=4.82$, $\mathrm{SD}=1.60)$ received lower ratings, the results were still fairly positive.

Table 3. Means and Standard Deviations of Intentions to teach

\begin{tabular}{llll}
\hline & \multicolumn{1}{c}{ Items } & $\mathrm{M}$ & $\mathrm{SD}$ \\
\hline B1 & I plan to apply for teaching career. & 5.31 & 1.63 \\
B2 & I intend to pursue teaching career. & 5.24 & 1.60 \\
B3 & I am committed to teaching career. & 4.59 & 1.67 \\
B4 & It is likely that I will pursue teaching career. & 5.39 & 1.46 \\
B5 & I have resolved to follow this occupational path. & 4.82 & 1.60 \\
\hline
\end{tabular}

\section{Motivations for teaching}

Figure 3 below illustrates the overall mean ratings of the factors influencing teaching choice. The results revealed that there existed little distinct differences in mean ratings across motivational factors as they ranged from 3.42 to 5.13 , with the highest ratings be prior teaching and learning experience $(\mathrm{M}=5.13, \mathrm{SD}=1.40)$, shape future of children/adolescents $(\mathrm{M}=5.10$, $\mathrm{SD}=1.41)$, and make social contribution $(\mathrm{M}=$ $4.89, \mathrm{SD}=1.52)$, and the lowest ratings belong to fallback career $(\mathrm{M}=3.42, \mathrm{SD}=1.94)$, job transferability $(\mathrm{M}=3.77, \mathrm{SD}=1.61)$ and time for family $(\mathrm{M}=3.95, \mathrm{SD}=1.76)$. 


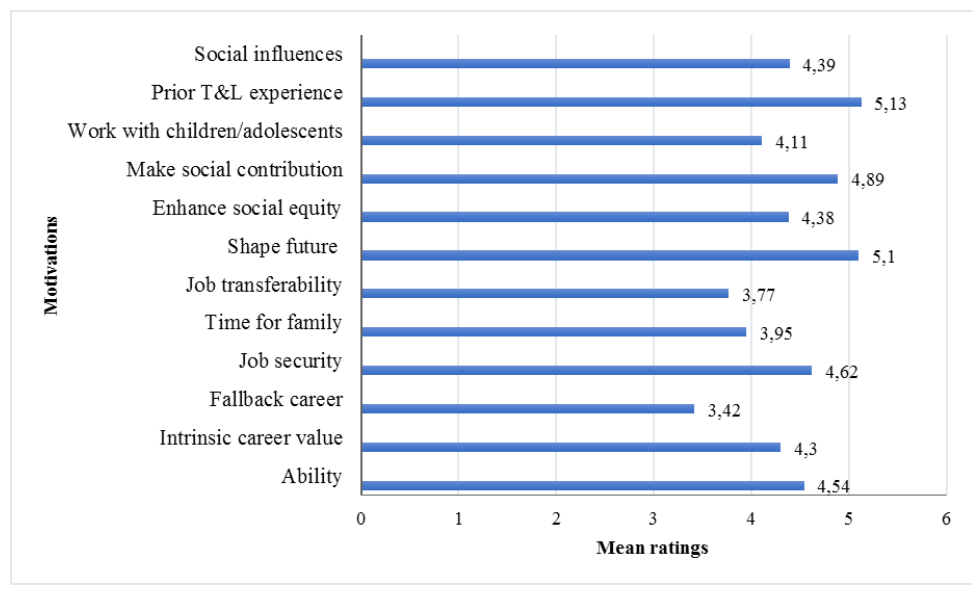

Figure 3. Factors influencing teaching choice of participants

The highest-rated factors. The means (M) and standard deviation (SD) of the highestrated factors influencing teaching choice across items were presented in Table 4 . To be specific, regarding the three items comprising prior teaching and learning experience factor, two involved having inspirational and good teachers and the other stressed on the overall positive learning experiences. Of the three items mentioned (items B15, B27, B33), the two first items namely having an inspirational teacher $(\mathrm{M}=5.20, \mathrm{SD}=1.32)$ and having good teachers as role models $(\mathrm{M}=5.18, \mathrm{SD}$ $=1.59$ ) show the highest level of agreement among participants. The last item in this construct concerning having positive learning experience $(\mathrm{M}=5.03, \mathrm{SD}=1.30)$ also shows a fairly positive result. When it comes to shaping future of children/adolescents, the desire to shape values of children/adolescents was the highest agreed item $(\mathrm{M}=5.20, \mathrm{SD}=$ 1.48), followed by participants' wish to influence the next generation $(\mathrm{M}=5.11, \mathrm{SD}=$ 1.37) and their ambitions to have an impact on children/adolescents $(\mathrm{M}=5.00, \mathrm{SD}=1.39)$. As for make social contribution, the data also indicate that participants in the current study generally believed that teachers were the ones who make worthwhile social contribution (M $=5.19, \mathrm{SD}=1.41$ ), provide service to society $(\mathrm{M}=4.83, \mathrm{SD}=1.60)$ and have chance to give back to society $(\mathrm{M}=4.67, \mathrm{SD}=1.54)$.

Table 4. Means (M) and Standard Deviation (SD)

of highest-rated factors influencing teaching choice

\begin{tabular}{lllll}
\hline & & \multicolumn{1}{c}{ Item } & M & SD \\
\hline $\begin{array}{llll}\text { Prior teaching and } \\
\text { learning experience }\end{array}$ & C15 & I have had inspirational teachers. & 5.18 & 1.59 \\
& C27 & I have good teachers as role models. & 5.20 & 1.32 \\
& C33 & I have had positive learning experience. & 5.03 & 1.30 \\
\hline $\begin{array}{l}\text { Shaping future of } \\
\text { children/adolescents }\end{array}$ & C9 & $\begin{array}{l}\text { Teaching will allow me to shape children and } \\
\text { adolescent values. }\end{array}$ & 5.20 & 1.48 \\
& C20 & $\begin{array}{l}\text { Teaching will allow me to influence the next } \\
\text { generation. }\end{array}$ & 5.11 & 1.37 \\
& C25 & $\begin{array}{l}\text { Teaching will allow me to have an impact on } \\
\text { children and adolescents. }\end{array}$ & 5.00 & 1.39 \\
\hline Make social contribution & C6 & Teaching will allow me to provide a service to society. & 4.83 & 1.60 \\
& C18 & Teachers make a worthwhile social contribution. & 5.19 & 1.41 \\
& C28 & Teaching enables me to give back to society. & 4.67 & 1.54 \\
\hline
\end{tabular}


The lowest-rated factors. The lowestrated motivations were fallback career, job transferability, and time for family. The mean scores for individual items ranged from 2.87 to 4.31 (see Table 5). Specifically, among the three items of fallback career, the results showed that failure to be accepted into firstchoice career was the least agreed option $(\mathrm{M}=2.87, \mathrm{SD}=1.94)$. The other two items of the same factor demonstrate fairly to considerably higher mean scores of 3.29 for choosing teaching as last-resort career (SD $=1.91$ ) and 4.12 for uncertainty on career path $(\mathrm{SD}=1.94)$. Interestingly, this factor also displayed the highest inconsistency in participants' opinions in comparison with other eleven motivational factors presented. Among the three items of job transferability, that teaching job allows desirable living place (M $=3.52, \mathrm{SD}=1.57)$ and its usefulness as a job for travelling $(\mathrm{M}=3.61, \mathrm{SD}=1.62)$ received slight disagreements from respondents. At the same time, for teaching qualification being widely recognized, participants tended to take the neutral stance as the mean score was 4.19 (SD = 1.63). Concerning the time for family factor, the results showed that short workday $(\mathrm{M}=3.20, \mathrm{SD}=1.65)$ was the least preferred reason leading to decision to teach. While respondents displayed a neutral view on choosing teaching career for lengthy holiday $(\mathrm{M}=3.97, \mathrm{SD}=1.94)$ and responsibilities of having a family $(M=4.08, S D=1.70)$, they generally agreed to pursue this career path for family reasons (i.e., having more family time $[\mathrm{M}=4.31, \mathrm{SD}=1.82]$; school holidays fit with family commitments $[\mathrm{M}=4.22, \mathrm{SD}=1.65]$ ).

The same patterns were observed across genders. In other words, participants in the current study would be most likely to follow a teaching career if they have experienced positive prior teaching and learning experience, had a desire to shape future of children/adolescents, and wished to make social contribution.

Table 5. Means (M) and Standard Deviation (SD) of lowest-rated factors influencing teaching choice

\begin{tabular}{lllll}
\hline & & \multicolumn{1}{c}{ Item } & M & SD \\
\hline Fallback career & C10 & I was unsure of what career I wanted. & 4.12 & 1.94 \\
& C29 & I was not accepted into my first-choice career. & 2.87 & 1.96 \\
& C37 & I chose teaching as a last-resort career. & 3.29 & 1.91 \\
\hline Job transferability & C8 & Teaching will be a useful job for me to have when travelling. & 3.61 & 1.62 \\
& C19 & Teaching qualification is recognized everywhere. & 4.19 & 1.63 \\
& C36 & A teaching job will allow me to choose where I wish to live. & 3.52 & 1.57 \\
\hline Time for family & C2 & Part-time teaching could allow more family time. & 4.31 & 1.82 \\
& C4 & As a teacher I will have lengthy holiday. & 3.97 & 1.94 \\
& C14 & Teaching hours will fit with the responsibilities of having a & 4.08 & 1.70 \\
& & family. & 3.20 & 1.70 \\
& C16 & As a teacher I will have a short workday. & 4.22 & 1.65 \\
\hline
\end{tabular}

Perceptions about the profession and satisfaction with choice

Generally, the participants perceived teaching as a profession that is high in not only task demand but also task return (see Figure 4). Regarding the expert career, participants mostly rated teaching as an expert career $(\mathrm{M}=5.55, \mathrm{SD}=1.08)$ - which requires the possession of both specialized and technical knowledge. They also believed that this occupation was rewarding in terms of social status $(\mathrm{M}=5.36, \mathrm{SD}=1.56)$ and teacher morale $(\mathrm{M}=4.97, \mathrm{SD}=1.15)$. Especially, for the item D12 on the teaching 
career's being perceived as a well-respected occupation, more than $85 \%$ of the participants showed moderate to strong agreements to this statement. However, at the same time, participants also stated that teaching career offered a low salary $(\mathrm{M}=3.82, \mathrm{SD}=1.49)$. Concerning the social dissuasion, the result indicated participants' neutral stance on this factor $(\mathrm{M}=4.03, \mathrm{SD}=1.63)$. The results from independent-samples t-Test showed that the differences in opinions regarding perceptions about teaching across genders were insignificant.

As for satisfaction with teaching choice, perceiving teaching career as being high in task demand (expert career and high demand) and social status but low in salary, participants demonstrated a fair level of satisfaction with their choice of becoming teachers (see Table 6). Of all the population, more than $73 \%$ of the participants believed that they had thought carefully about becoming a teacher, 61.4\% of them felt satisfied with their choice and more than $60 \%$ of the population stated that they were happy with their decision. The difference regarding satisfaction with choice across genders were, again, insignificant.

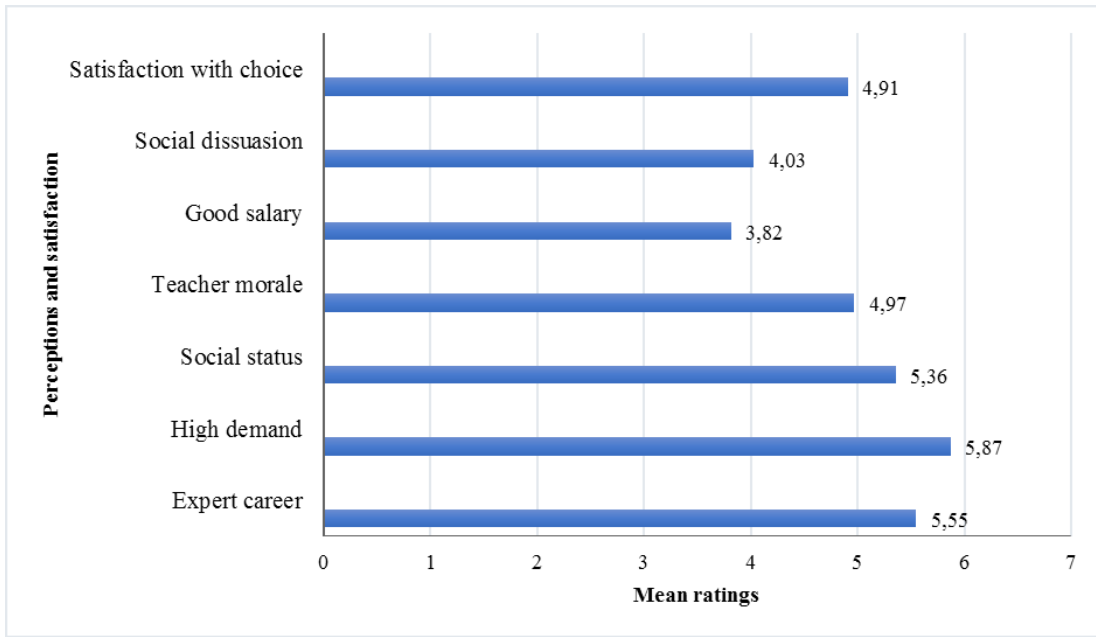

Figure 4. Perceptions about teaching and satisfaction with choice

Table 6. Mean (M) and Standard Deviation (SD) of satisfaction with choice

\begin{tabular}{lcc}
\hline & $\mathrm{M}$ & $\mathrm{SD}$ \\
\hline D15-How carefully have you thought about becoming a teacher? & 5.31 & 1.22 \\
D17-How satisfied are you with your choice of becoming a teacher? & 4.72 & 1.36 \\
D19-How happy are you with your decision of becoming a teacher? & 4.70 & 1.34 \\
\hline
\end{tabular}

Correlations between intentions of becoming teacher and motivations to teach

Table $7 \mathrm{a}$ and $7 \mathrm{~b}$ presented the Pearson correlations across the 20 constructs including intentions to teach, motivations, perceptions about teaching career, and satisfaction with choice. Factors that had strongest correlations with intentions to pursuing teaching career included: intrinsic career value $(\mathrm{r}=.67, \mathrm{p}<$ 0.01 ), followed by enhance social equity ( $\mathrm{r}$ $=.44, \mathrm{p}<0.01)$, prior teaching and learning experience $(\mathrm{r}=.46, \mathrm{p}<0.01)$, ability $(\mathrm{r}=.48$, $\mathrm{p}<0.01)$, and make social contribution $(\mathrm{r}=$ $.51, \mathrm{p}<0.01)$. Work with children/adolescents $(\mathrm{r}=.25, \mathrm{p}<0.01)$, job security $(\mathrm{r}=.26, \mathrm{p}<$ $0.01)$, time for family $(\mathrm{r}=.26, \mathrm{p}<0.01)$ also demonstrated positive relationships with 
participants' intentions to teach, although the strength of the relationship was small. Of interest was the negative correlation between fallback career and intentions to teach $(\mathrm{r}=$ $-.27, \mathrm{p}<0.01)$ and the fact that a number of perception constructs (i.e., expert career, high demand, social status, teacher morale, good salary, social dissuasion) were found to have insignificant correlations with an individual's intention to pursue a teaching career. Finally, regarding the last construct of satisfaction with choice, its relationship with intention to teach $(\mathrm{r}=.65, \mathrm{p}<0.01)$ was estimated to be statistically strong.

Table 7a. Correlations across Intention of becoming teachers and Motivational factors for teaching

\begin{tabular}{|c|c|c|c|c|c|c|c|c|c|c|c|c|c|c|}
\hline & & 1 & 2 & 3 & 4 & 5 & 6 & 7 & 8 & 9 & 10 & 11 & 12 & 13 \\
\hline 1. Intentions to teach & $\begin{array}{l}\text { Pearson Correlation } \\
\text { Sig. (2-tailed) }\end{array}$ & 1 & & & & & & & & & & & & \\
\hline 2. Ability & $\begin{array}{l}\text { Pearson Correlation } \\
\text { Sig. (2-tailed) }\end{array}$ & $\begin{array}{r}.48^{* *} \\
.00 \\
\end{array}$ & 1 & & & & & & & & & & & \\
\hline 3. Intrinsic career value & $\begin{array}{l}\text { Pearson Correlation } \\
\text { Sig. (2-tailed) }\end{array}$ & $\begin{array}{r}.67^{*+*} \\
.00 \\
\end{array}$ & $\begin{array}{r}.67^{*+} \\
.00 \\
\end{array}$ & 1 & & & & & & & & & & \\
\hline 4. Fallback career & $\begin{array}{l}\text { Pearson Correlation } \\
\text { Sig. (2-tailed) }\end{array}$ & $\begin{array}{r}-.27^{*+} \\
.00\end{array}$ & $\begin{array}{r}-.17 \\
.07\end{array}$ & $\begin{array}{r}-.33^{*+} \\
.00\end{array}$ & 1 & & & & & & & & & \\
\hline 5. Job security & $\begin{array}{l}\text { Pearson Correlation } \\
\text { Sig. (2-tailed) }\end{array}$ & $\begin{array}{r}.25^{* *} \\
.01 \\
\end{array}$ & $\begin{array}{r}.30^{* *} \\
.00 \\
\end{array}$ & $\begin{array}{l}.13 \\
.14 \\
\end{array}$ & $\begin{array}{r}.18^{*} \\
.04\end{array}$ & 1 & & & & & & & & \\
\hline 6. Time for family & $\begin{array}{l}\text { Pearson Correlation } \\
\text { Sig. (2-tailed) }\end{array}$ & $\begin{array}{r}.26^{*+} \\
.01 \\
\end{array}$ & $\begin{array}{r}.29^{* *} \\
.00 \\
\end{array}$ & $\begin{array}{r}.25^{* *} \\
.00 \\
\end{array}$ & $\begin{array}{r}.34^{* *} \\
.00 \\
\end{array}$ & $\begin{array}{l}.58^{* 4} \\
.00\end{array}$ & 1 & & & & & & & \\
\hline 7. Job transferability & $\begin{array}{l}\text { Pearson Correlation } \\
\text { Sig. (2-tailed) }\end{array}$ & $\begin{array}{r}.29^{* *} \\
.00\end{array}$ & $\begin{array}{r}.44^{* *} \\
.00\end{array}$ & $\begin{array}{r}.36^{* *} \\
.00\end{array}$ & $\begin{array}{r}.27^{* *} \\
.00\end{array}$ & $\begin{array}{l}.58^{* *} \\
.00\end{array}$ & $\begin{array}{r}.68^{* *} \\
.00\end{array}$ & 1 & & & & & & \\
\hline $\begin{array}{l}\text { 8. Shape future of children } \\
\text { and adolescents }\end{array}$ & $\begin{array}{l}\text { nPearson Correlation } \\
\text { Sig. (2-tailed) }\end{array}$ & $\begin{array}{r}.39^{* *} \\
.00\end{array}$ & $\begin{array}{r}.48^{* *} \\
.00\end{array}$ & $\begin{array}{r}.45^{* *} \\
.00\end{array}$ & $\begin{array}{r}-.14 \\
.12\end{array}$ & $\begin{array}{r}.25^{* *} \\
.00\end{array}$ & $\begin{array}{r}.18^{*} \\
.04\end{array}$ & $\begin{array}{r}.29^{* *} \\
.00\end{array}$ & 1 & & & & & \\
\hline 9. Enhance social equity & $\begin{array}{l}\text { Pearson Correlation } \\
\text { Sig. (2-tailed) }\end{array}$ & $\begin{array}{r}.44^{*+*} \\
.00 \\
\end{array}$ & $\begin{array}{r}.46^{*+*} \\
.00 \\
\end{array}$ & $\begin{array}{l}.38^{*+*} \\
.000 \\
\end{array}$ & $\begin{array}{r}-.00 \\
.98\end{array}$ & $\begin{array}{r}.36^{* 4} \\
.00\end{array}$ & $\begin{array}{r}.09^{*+4} \\
.00\end{array}$ & $\begin{array}{r}.06^{*+} \\
.00\end{array}$ & $\begin{array}{r}.52^{*+} \\
.00\end{array}$ & 1 & & & & \\
\hline $\begin{array}{r}\text { 10. Make social } \\
\text { contribution }\end{array}$ & $\begin{array}{l}\text { Pearson Correlation } \\
\text { Sig. (2-tailed) }\end{array}$ & $\begin{array}{r}.51^{*+} \\
.00 \\
\end{array}$ & $\begin{array}{r}.58^{*+} \\
.00 \\
\end{array}$ & $\begin{array}{r}.57^{*+} \\
.00 \\
\end{array}$ & $\begin{array}{r}-.27^{*+} \\
.00 \\
\end{array}$ & $\begin{array}{l}.27^{4+4} \\
.00\end{array}$ & $\begin{array}{r}.18^{4} \\
.04 \\
\end{array}$ & $\begin{array}{r}.35^{*+} \\
.00\end{array}$ & $\begin{array}{r}.59^{*+} \\
.00 \\
\end{array}$ & $\begin{array}{r}.65^{*+} \\
.00\end{array}$ & 1 & & & \\
\hline $\begin{array}{l}\text { 11. Work with } \\
\text { children/adolescents }\end{array}$ & $\begin{array}{l}\text { Pearson Correlation } \\
\text { Sig. (2-tailed) }\end{array}$ & $\begin{array}{r}.25^{* *} \\
.01 \\
\end{array}$ & $\begin{array}{r}.44^{* *} \\
.00 \\
\end{array}$ & $\begin{array}{r}.49^{* *} \\
.00\end{array}$ & $\begin{array}{r}-.00 \\
.96 \\
\end{array}$ & $\begin{array}{l}.13 \\
.14 \\
\end{array}$ & $\begin{array}{r}.36^{* *} \\
.00 \\
\end{array}$ & $\begin{array}{r}.35^{* *} \\
.00 \\
\end{array}$ & $\begin{array}{r}.49^{* *} \\
.00 \\
\end{array}$ & $\begin{array}{r}.32^{* *} \\
.00 \\
\end{array}$ & $\begin{array}{r}.34^{* *} \\
.00 \\
\end{array}$ & 1 & & \\
\hline $\begin{array}{l}\text { 12. Prior teaching and } \\
\text { learning exnerience }\end{array}$ & $\begin{array}{l}\text { Pearson Correlation } \\
\text { Sig. (2-tailed) }\end{array}$ & $\begin{array}{r}.46^{*+} \\
.00\end{array}$ & $\begin{array}{r}.45^{* *} \\
.00\end{array}$ & $\begin{array}{r}.54^{*+} \\
.00\end{array}$ & $\begin{array}{r}-.29^{* *} \\
.00\end{array}$ & $\begin{array}{l}.26^{*+} \\
.00\end{array}$ & $\begin{array}{l}.14 \\
.13\end{array}$ & $\begin{array}{r}.26^{*+} \\
.00\end{array}$ & $\begin{array}{r}.44^{*+} \\
.00\end{array}$ & $\begin{array}{r}.44^{*+} \\
.00\end{array}$ & $\begin{array}{r}.61^{\circ} \\
.00\end{array}$ & $\begin{array}{r}.25^{*+} \\
.00\end{array}$ & 1 & \\
\hline 13. Social influences & $\begin{array}{l}\text { Pearson Correlation } \\
\text { Sig. (2-tailed) }\end{array}$ & $\begin{array}{l}.19^{*} \\
.04\end{array}$ & $\begin{array}{r}.43^{* *} \\
.00 \\
\end{array}$ & $\begin{array}{r}.31^{* *} \\
.00 \\
\end{array}$ & $\begin{array}{l}.13 \\
.15\end{array}$ & $\begin{array}{r}.31^{* *} \\
.00\end{array}$ & $\begin{array}{r}.42^{* *} \\
.00 \\
\end{array}$ & $\begin{array}{r}.56^{* *} \\
.00 \\
\end{array}$ & $\begin{array}{l}.09 \\
.32 \\
\end{array}$ & $\begin{array}{r}.27^{* *} \\
.00 \\
\end{array}$ & $\begin{array}{r}.25^{* *} \\
.00 \\
\end{array}$ & $\begin{array}{l}.16 \\
.07 \\
\end{array}$ & $\begin{array}{r}.26^{* *} \\
.00\end{array}$ & $\overline{1}$ \\
\hline 14. Expert career & $\begin{array}{l}\text { Pearson Correlation } \\
\text { Sig. (2-tailed) }\end{array}$ & $\begin{array}{l}.11 \\
.26\end{array}$ & .11 & .06 & $\begin{array}{r}-.00 \\
.99\end{array}$ & $\begin{array}{l}.20^{*} \\
.03\end{array}$ & $\begin{array}{l}.06 \\
.46\end{array}$ & $\begin{array}{l}.09 \\
.34\end{array}$ & $\begin{array}{l}.21^{*} \\
.02\end{array}$ & .16 & $.26^{* *}$ & $\begin{array}{l}.00 \\
.99\end{array}$ & $.31^{* *}$ & .01 \\
\hline 15. High demand & $\begin{array}{l}\text { Pearson Correlation } \\
\text { Sig. (2-tailed) }\end{array}$ & $\begin{array}{l}.02 \\
.86\end{array}$ & $\begin{array}{r}-.03 \\
.71\end{array}$ & $\begin{array}{r}-.02 \\
.78\end{array}$ & $\begin{array}{r}-.14 \\
.12\end{array}$ & $\begin{array}{r}-.03 \\
.67\end{array}$ & $\begin{array}{r}-.22^{*} \\
.01\end{array}$ & $\begin{array}{r}-.20^{*} \\
.03\end{array}$ & $\begin{array}{r}-.03 \\
.75\end{array}$ & $\begin{array}{l}.09 \\
.32\end{array}$ & $\begin{array}{r}-.01 \\
.88\end{array}$ & $\begin{array}{r}-.06 \\
.49\end{array}$ & $\begin{array}{l}.16 \\
.07\end{array}$ & $\begin{array}{r}-.04 \\
.65\end{array}$ \\
\hline 16. Social status & $\begin{array}{l}\text { Pearson Correlation } \\
\text { Sig. (2-tailed) }\end{array}$ & $\begin{array}{l}.00 \\
.03 \\
.77\end{array}$ & $\begin{array}{l}.17 \\
.06 \\
\end{array}$ & $\begin{array}{r}.013 \\
.88 \\
\end{array}$ & $\begin{array}{l}.12 \\
.02 \\
.79 \\
\end{array}$ & $\begin{array}{l}. .22^{*} \\
.01 \\
\end{array}$ & $\begin{array}{l}.07 \\
.44 \\
\end{array}$ & $\begin{array}{l}.05 \\
.21 \\
\end{array}$ & $\begin{array}{r}.18^{*} \\
.04 \\
\end{array}$ & $\begin{array}{r}. .23 \\
.23^{*} \\
.01\end{array}$ & $\begin{array}{l}.00 \\
.15 \\
.10 \\
\end{array}$ & $\begin{array}{l}.45 \\
.04 \\
\end{array}$ & $\begin{array}{r}.03^{*} \\
.01 \\
\end{array}$ & $\begin{array}{l}. .05 \\
.02 \\
.02 \\
\end{array}$ \\
\hline 17. Teacher morale & $\begin{array}{l}\text { Pearson Correlation } \\
\text { Sig. (2-tailed) }\end{array}$ & $\begin{array}{l}.12 \\
.12\end{array}$ & $\begin{array}{l}.21^{*} \\
.02\end{array}$ & $\begin{array}{l}.05 \\
.54\end{array}$ & $\begin{array}{r}-.05 \\
.53\end{array}$ & $\begin{array}{r}.21^{*} \\
.02\end{array}$ & $\begin{array}{l}.23^{4} \\
.01\end{array}$ & $\begin{array}{l}.13 \\
.14\end{array}$ & $\begin{array}{l}.10 \\
.28\end{array}$ & $\begin{array}{l}.05 \\
.56\end{array}$ & $\begin{array}{l}.08 \\
.38\end{array}$ & $\begin{array}{l}.16 \\
.08\end{array}$ & $\begin{array}{l}.10 \\
.27\end{array}$ & $\begin{array}{r}.24^{* 4} \\
.00\end{array}$ \\
\hline 18. Good salary & $\begin{array}{l}\text { Pearson Correlation } \\
\text { Sig. (2-tailed) }\end{array}$ & $\begin{array}{l}.12 \\
.29\end{array}$ & $\begin{array}{l}.02 \\
.16\end{array}$ & .14 & .14 & $\begin{array}{l}.07^{*+} \\
.000\end{array}$ & $\begin{array}{r}.29^{* *} \\
.00\end{array}$ & $\begin{array}{l}.31^{+*} \\
.00\end{array}$ & $\begin{array}{r}.20 \\
-.07 \\
.45\end{array}$ & $\begin{array}{r}.24^{*+} \\
.00\end{array}$ & $\begin{array}{l}.15 \\
.10\end{array}$ & $\begin{array}{r}.00 \\
.14 \\
.13\end{array}$ & $\begin{array}{l}.21 \\
.16\end{array}$ & $\begin{array}{r}.35^{44} \\
.00\end{array}$ \\
\hline 19. Social dissuasion & $\begin{array}{l}\text { Pearson Correlation } \\
\text { Sig. (2-tailed) }\end{array}$ & $\begin{array}{r}-.11 \\
.26\end{array}$ & $\begin{array}{l}.09 \\
.35\end{array}$ & $\begin{array}{l}.12 \\
.17\end{array}$ & $\begin{array}{l}.08 \\
.36\end{array}$ & $\begin{array}{l}.02 \\
.78 \\
\end{array}$ & $\begin{array}{l}.05 \\
.56\end{array}$ & $\begin{array}{l}.19^{*} \\
.03\end{array}$ & $\begin{array}{l}.00 \\
.95\end{array}$ & $\begin{array}{l}.11 \\
.24\end{array}$ & $\begin{array}{r}-.03 \\
.71 \\
\end{array}$ & $\begin{array}{l}.10 \\
.25 \\
\end{array}$ & $\begin{array}{r}-.09 \\
.30\end{array}$ & $\begin{array}{l}.11 \\
.22\end{array}$ \\
\hline 20. Satisfaction with choice & $\begin{array}{l}\text { Pearson Correlation } \\
\text { Pig. (2-tailed) }\end{array}$ & $\begin{array}{l}.65^{* *} \\
.00\end{array}$ & $\begin{array}{r}.61^{* *} \\
.00\end{array}$ & $\begin{array}{r}.64^{* *} \\
.00\end{array}$ & $\begin{array}{r}. .38^{* *} \\
.00\end{array}$ & $\begin{array}{l}.18 \\
.05\end{array}$ & $\begin{array}{l}.16 \\
.08\end{array}$ & $\begin{array}{r}.32^{* *} \\
.00\end{array}$ & $\begin{array}{r}.42^{* *} \\
.00\end{array}$ & $\begin{array}{r}.39^{* *} \\
.00\end{array}$ & $\begin{array}{r}.52^{* *} \\
.00\end{array}$ & $\begin{array}{r}.37^{* *} \\
.00\end{array}$ & $\begin{array}{r}.51^{* * *} \\
.00\end{array}$ & $\begin{array}{l}.21^{*} \\
.02\end{array}$ \\
\hline
\end{tabular}

Table $7 \mathrm{~b}$. Correlations across Intention of becoming teachers and Perceptions about teaching and satisfaction with choice

\begin{tabular}{|c|c|c|c|c|c|c|c|c|}
\hline & & 14 & 15 & 16 & 17 & 18 & 19 & 20 \\
\hline 11. Work with children/adolescents & $\begin{array}{l}\text { Pearson Correlation } \\
\text { Sig. (2-tailed) }\end{array}$ & & & & & & & \\
\hline 12. Prior teaching and learning experience & $\begin{array}{l}\text { Pearson Correlation } \\
\text { Sig. (2-tailed) }\end{array}$ & & & & & & & \\
\hline 13. Social influences & $\begin{array}{l}\text { Pearson Correlation } \\
\text { Sig. (2-tailed) }\end{array}$ & & & & & & & \\
\hline 14. Expert career & $\begin{array}{l}\text { Pearson Correlation } \\
\text { Sig. (2-tailed) }\end{array}$ & 1 & & & & & & \\
\hline 15. High demand & $\begin{array}{l}\text { Pearson Correlation } \\
\text { Sig. (2-tailed) }\end{array}$ & $\begin{array}{r}.28^{*+4} \\
.00\end{array}$ & 1 & & & & & \\
\hline 16. Social status & $\begin{array}{l}\text { Pearson Correlation } \\
\text { Sig. (2-tailed) }\end{array}$ & $\begin{array}{r}.41^{* *} \\
.00 \\
\end{array}$ & $\begin{array}{r}.36^{* *} \\
.00 \\
\end{array}$ & 1 & & & & \\
\hline 17. Teacher morale & $\begin{array}{l}\text { Pearson Correlation } \\
\text { Sig. (2-tailed) }\end{array}$ & $\begin{array}{r}.27^{* *} \\
.00 \\
\end{array}$ & $\begin{array}{l}.02 \\
.75 \\
\end{array}$ & $\begin{array}{r}.60^{* *} \\
.00 \\
\end{array}$ & 1 & & & \\
\hline 18. Good salary & $\begin{array}{l}\text { Pearson Correlation } \\
\text { Sig. (2-tailed) }\end{array}$ & $\begin{array}{l}.21^{*} \\
.02\end{array}$ & $\begin{array}{r}-.02 \\
.79\end{array}$ & $\begin{array}{l}.21^{*} \\
.02\end{array}$ & $\begin{array}{l}.22^{*} \\
.01\end{array}$ & 1 & & \\
\hline 19. Social dissuasion & $\begin{array}{l}\text { Pearson Correlation } \\
\text { Sig. (2-tailed) }\end{array}$ & $\begin{array}{r}-.16 \\
.08\end{array}$ & $\begin{array}{r}-.13 \\
.14\end{array}$ & $\begin{array}{r}-.20^{*} \\
.03\end{array}$ & $\begin{array}{r}-.23^{*} \\
.01\end{array}$ & $\begin{array}{r}-.09 \\
.33\end{array}$ & 1 & \\
\hline 20. Satisfaction with choice & $\begin{array}{l}\text { Pearson Correlation } \\
\text { Sig. (2-tailed) }\end{array}$ & $\begin{array}{l}.15 \\
.10\end{array}$ & $\begin{array}{r}-.00 \\
.96\end{array}$ & $\begin{array}{l}.13 \\
.16\end{array}$ & $\begin{array}{l}.15 \\
.09\end{array}$ & $\begin{array}{l}.17 \\
.06\end{array}$ & $\begin{array}{l}.09 \\
.34\end{array}$ & \\
\hline
\end{tabular}

$* *$ Correlation is significant at the 0.01 level (2-tailed).
$*$ Correlation is significant at the 0.05 level (2-tailed) 
The hypothesis that social utility values such as make social contribution and shape future of children/adolescents as well as work with children/adolescents factors would show strong positive correlation with intentions to teach was not totally supported. The results from Pearson correlation analysis revealed that despite the fact that all three factors were statistically related to the intentions of becoming teachers, the strength of these relationships only ranged from weak to moderate. As for the prediction that fallback career, job transferability, and social influences would negatively correlate with teaching choice, the results indicated that only fallback career was negatively related to intentions to teach; the other two factors showed weak yet positive relationships with teaching intentions.

\section{Discussion}

The primary aims of this study were first to investigate participants' intentions to pursue teaching career; second, to examine the factors influencing their choices of teaching career in Vietnamese context; and finally, to explore the relationship between those factors and participants' intentions to teach.

From the data collected, it was observable that although the number of females enrolling in the particular English Language Teacher Education program outweighed that of males, statistics indicated no differences between the two genders in terms of their intentions to follow teaching career after graduating. Most of the participants demonstrated positive prospect of following the teaching career. Nevertheless, the considerable proportion of teacher trainees wishing to pursue careers other than teaching was alarming. This could be attributed to numerous factors, namely low salary, lack of job opportunity, lack of desire to change to make social contribution and so on (Pham, 2012). As for those who wish to follow the teaching career path in the future, the influential factors leading to their choice were discussed in the later parts.
Factors influencing intentions to teach

Highest-rated motivations. Results from the data analysis revealed that prior teaching and learning experiences as well as social utility values such as shape future of children/ adolescents and make social contribution were the highest-rated motivations influencing participants' teaching choice. These findings were of no great surprise as the application of FIT-Choice scale in numerous contexts have yielded similar results "“"i.e., Lin, Shi, Wang, Zhang \& Hui (2012); Kılınç, Watt and Richardson (2012)")". Given collectivism in Vietnam, in which people tend to work towards a common goal, participants' choice of becoming teachers to contribute to a better society is quite understandable.

However, in contrast with other Western countries and especially the Australian context, where the scale was originally developed and validated, perceived ability and intrinsic career value were not among the highest-rated factors in this study. Yet, the results appeared to be consistent with those from Chinese and Turkish contexts, in which prior teaching and learning experiences also played an important role in motivating prospective teachers (i.e., $\mathrm{M}=5.27$ and $\mathrm{M}=5.09$ in Turkish and Chinese settings respectively). Such comparability might be explained by the shared perceptions about the roles of teachers in Vietnam and China. In fact, both China and Vietnam could be classified as belonging to Confucian heritage culture, which highly appreciates teachers and the teaching career. According to Phan and Phan (2006), besides the roles of a knowledge deliverer, Vietnamese teachers also act as a moral guide. Teaching is regarded a high status and well-respected job, and students generally take their teachers as an exemplary model to follow. Therefore, it is likely that students are influenced by their teachers in many facets of life, including career choice decision. Similarly, the reverence for teacher profession are also observed in Chinese culture as Lin, Shi, Wang, Zhang and Hui (2012) pointed out 
that Chinese teachers are highly respected and considered the authority of knowledge. Chinese government policy also supports the positive image of teachers as respectful profession with bright career prospects. Consequently, students who witnessed the exhibition of such features from their teachers are more likely to follow teacher career. In other words, under the guidance of aspiring and motivating teachers, students might be more likely to display a desire to follow the teaching career path.

In a similar vein, perceived ability and intrinsic career value were highly rated in Western contexts but just scored a little bit above the midpoint in Eastern countries including Vietnam. One possible explanation is that rather than endorsing ability and intrinsic career value, prospective teachers in Vietnam and China might be more concerned about job security. As stated in Richardson, Karabenick and Watt (2014), this tendency among East Asia countries may stem from their collectivist cultures, in which individual interests have an inferior impact on career choice as compared with job security and benefits. In the Vietnamese context particularly, the education sector in Vietnam provides permanent teaching job for teachers that pass a civil service examination, which can help to secure the employed status, salary as well as other social benefits for their whole teaching career. That kind of "security" offered may be the more common reason behind many students' choices of teaching career (rather than perceived ability or intrinsic career value).

Lowest-rated motivations. Findings from this study revealed that fallback career and job transferability were the least preferred factors. There was a slight difference between the results from the current study and those from others on a similar topic. The fallback career factor ranked last in this study, which possibly indicated that few participants opted for teaching career as the last-resort choice when having failed other preferred options. However, when compared with other studies using FIT-Choice scale in Turkey (Kılınç, Watt \& Richardson, 2012), China (Lin, Shi, Wang, Zhang \& Hui, 2012), Australia (Watt \& Richardson, 2006), the Netherlands (Fokkens-Bruinsma \& Canrinus, 2012), Croatia (Jugović, Marušic, Ivanec, \& Vidovic, 2012), the fallback career motivation in this research still displayed a stronger influence on Vietnamese prospective teachers. According to Quyen (2018), many teacher training universities in 2018 received low entrance rate despite the low entrance scores, which may imply that teaching career may not be the most appealing and preferred profession to many students. Some students might have ended up in these universities as a result of the low scores and failure to be admitted to their desired programs. Intriguingly, regarding this fallback career motivations, the male participants were reported to be significantly unsure of what career to pursue in the future, which may suggest lower teaching retention of these respondents in comparison with that of female ones. Moreover, this fair rating of fallback career motivation might imply pessimistic future teaching career of participants as Richardson, Karabenick \& Watt (2014) suggested that fallback career motivation may result in negative teaching behaviors and consequently negative teaching practices. As for the factor of job transferability, the low ratings were also understandable given the contextual differences between Vietnam and Australia the context where the scale was developed and validated. In the Australian context, the national and international circulations of teachers are quite common whereas, in Vietnam, teachers generally enjoy less flexibility in terms of workplace change. For teachers working for government schools, such changes are even more limited as they must meet a certain number of demands according to Vietnamese Law on Public Employees (Luật Viên chức, 2010).

Perceptions about teaching. The results of this study were in line with those of research on similar topic terms of participants' perception teaching demand. To be specific, teaching occupation in Vietnam was perceived 
to not only require expert knowledge but also involve hard work as well as emotional demand. This finding supported the beliefs about teachers being considered knowledge expert suggested in Phan and Phan (2006). Regarding task return, participants believed that teachers earn a poor salary considering the hard work they have to deal with. The findings of McAleavy, Tran and Fitzpatrick (2018) also indicated a similar state when teachers "consider themselves badly paid and have to supplement their income by working as private tutors" (p. 22).

However, the research findings reported much higher values for social status factor with respect to other discoveries made by other studies using FIT-Choice scale. As suggested by McAleavy, Tran and Fitzpatrick (2018), the high ratings of teachers' social status suggested that teachers were believed to be members of a respected profession and this idea is supported by both cultural norms and government policies.

Satisfaction with choice. Participants of this study demonstrated a fair level of satisfaction with their career choice. Intriguingly, rather than statistically related to their perceptions about teaching career, participants' satisfaction with teaching choice were influenced by teaching motivations namely ability, intrinsic career value, fallback career, shape future of children/adolescents, make social contribution and prior teaching and learning experiences. The same findings were also found in $\mathrm{Yu}$ and Bieger (2013) when American pre-service teachers' contentment with their choice of teaching career also strongly related to their motivations for teaching.

\section{Correlations between factor influencing teaching choice and intentions to teach}

Intrinsic career value and satisfaction with choice were the two factors that showed the strongest correlations with teaching choice decision. This result corresponded with factors influencing behaviors namely expectancy of success (satisfaction with choice) and task value (intrinsic career value) as suggested in the expectancy-value theories (Wigfield \& Eccles, 2000), on which FIT-Choice scale was based. In other words, if students show a strong desire to teach and a complete satisfaction with their choice of teaching career, they are more likely to pursue teaching career in the future and vice versa. At the same time, perceived ability, social utility value such as making social contribution, shaping future of children/adolescents, and enhancing social equity as well as prior teaching and learning experience were moderately related to intentions to teach. These factors were also proved to be the highest influential factors behind one's intention to pursue teaching career in studies using FIT-Choice scale in different contexts including Vietnamese. The results also revealed that fallback career negatively correlated with intentions to teach, indicating that those who choose teaching as the last-resort career would show little hope to pursue teaching career later on.

\section{Implications}

This study has contributed to the existing literature on factors influencing teaching choice (FIT-Choice) in different contexts. Moreover, the research has also revealed the relationship between prospective teachers' intentions to teach and their motivations to teach, which may assist educators/teacher trainers in promoting desire to become teachers among students.

First and foremost, since positive prior teaching and learning experience was found to be the most influential motivators behind one's decision to follow teaching career path, it is important that educators through their teaching provide those prospective teachers with positive learning experiences. Research on qualities of English teachers in Vietnam, though limited, has revealed that teacher's expert knowledge of the subject, pedagogic skills, professional behaviors and personal characteristics are all fundamental to quality 
teaching and learning (Tran, 2015). Besides, McKnight, Graybeal, Yarbro and Graybeal (2016) also highlighted the role of teacher's relationship with learners, teacher's patience, caring, and dedication in effective teaching. In fact, the necessity to build a trusting and compassionate relationship between teacher and students has been highly endorsed by all Vietnamese stakeholders of education (i.e., parents, students, policy makers, principals, and teachers). It is believed that such interpersonal relationships would not only facilitate the education process but also have potential impact on students' motivation to be a teacher. Moreover, since intrinsic career value - which concerns one's interest and desire for teaching profession - shows the strongest correlation with intentions to teach as well as satisfaction with choice, creating a good image of teacher and a bright prospect of teaching career might help to attract more students in this profession.

The practice of effective teacher qualities above also expected to promote students' motivation to make social contribution and shape future of children/adolescents. Specifically, as stated in Phan and Phan (2006), Vietnamese teachers take the roles of knowledge expert and moral guide for students to follow. Therefore, when teachers are considered effective and worth respecting, their knowledge and actions may positively affect the academic performances, moral behaviors, and later future of students. Besides teachers' self-practice of five aforementioned qualities, it is advisable that the government help raise people awareness about the importance of education in shaping one's future, which later highlights teachers' contribution to the educational mobilization for the nation.

At program level, practical components such as the micro-teaching and teaching practicum when conducted effectively may also help these students enhance their teaching knowledge and skills, as well as form a positive experience about teaching as a profession. Volunteering teaching activities (i.e., teaching disadvantaged kids during a summer program, volunteering for an education organization, etc.) may help students build up their knowledge of the teaching career and feel that they are making worthwhile contributions to the society through teaching.

\section{Limitations and suggestions for further research}

Although care was taken during the whole process to minimize errors and ensure the reliability and validity of the research findings, the following limitations were unavoidable and need to be acknowledged. Firstly, due to the low response rate (about $60.8 \%$ ), findings from the study may not necessarily represent the opinions of all senior ELTE students. Secondly, due to limited time and human resource, the researchers could not dig deep into the reasons for not choosing teaching profession as well as seek further explanations on factors influencing their career choices. Further research on the similar topic could take into consideration the application of interviews (together with questionnaires) to gain a better understanding on the matters revolving participants' teaching choice.

\section{References}

\section{Vietnamese}

Đinh Viết Thắng (2012). Bàn về người thầy trong xã hội phong kiến. Retrieved from http://tcsnd5.edu.vn/ index.php/giao-d-c-dao-t-o/bai-vi-t-v-giao-d-c/50ban-v-ngu-i-th-y-trong-xa-h-i-phong-ki-n

Lê Văn Canh, Nguyễn Thị Ngọc (2017). Đề án Ngoại ngữ Quốc gia 2020 có thể học được gì từ kinh nghiệm châu Á? VNU Journal of Foreign Studies, 33. doi: $10.25073 / 2525-2445 /$ vnufs. 4166 .

Ministry of Finance (MOF) (2018). Hướng dẫn quản lý, sư dưng kinh phi thực hiện Quyết định số 2080/ QĐ-TTg ngày 22 tháng 12 năm 2017 của Thủ tuớng Chinh phủ về việc phê duyệt điều chỉnh, bổ sung Đề án dạ và học ngoại ngũ trong hệ thống giáo duc quốc dân giai đoạn 2017 - 2025[Ebook]. Ha Noi: Vietnamese Ministry of Finance.

Nguyễn Cao (2019). Ai đảm bảo tương lai sinh viên su phạm sẽ có nhiều cơ hội việc làm hơn?. Retrieved from https://giaoduc.net.vn/Giao-duc-24h/Ai-dam- 
bao-tuong-lai-sinh-vien-su-pham-se-co-nhieu-cohoi-viec-lam-hon-post196685.gd

Nguyễn Hà Phương (2017). Không miễn học phí cho sinh viên sư phạm làm trái ngành. Retrieved from https://news.zing.vn/khong-mien-hoc-phi-cho-sinhvien-su-pham-lam-trai-nganh-post788480.html

Nguyễn Quỳnh Trang (2018). Hơn 120.000 nguyện vọng đăng ký vào ngành Sư phạm. Retrieved from https:// vnexpress.net/giao-duc/hon-120-000-nguyen-vongdang-ky-vao-nganh-su-pham-3742469.html

Luật Viên chức. (2010). Retrieved from http://vanban. chinhphu.vn/portal/page/portal/chinhphu/ hethongvanban? class_id=1\&mode $=$ detail\&document id $=98566$

Nguyễn Tú Uyên (2018). Nóng Kỳ thi THPT Quốc gia 2018: Chỉ tiêu Sư phạm giảm mạnh 38\%. Retrieved from https:/vietnammoi.vn/nong-ky-thi-thpt-quoc-gia2018-chi-tieu-su-pham-giam-manh-38-97619.html

Quyên Quyên (2018). Nghịch lý đào tạo su phạm: Điểm chuẩn thấp hay cao vẫn vắng thi sinh. Retrieved from https://news.zing.vn/nghich-ly-dao-tao-supham-diem-chuan-thap-hay-cao-van-vang-thi-sinhpost869313.html

\section{English}

Berger, J., \& D'Ascoli, Y. (2012). Becoming a VET teacher as a second career: investigating the determinants of career choice and their relation to perceptions about prior occupation. Asia-Pacific Journal of Teacher Education, 40, 317-341. doi: 10.1080/1359866x.2012.700046.

Fokkens-Bruinsma, M., \& Canrinus, E. T. (2012). The Factors Influencing Teaching (FIT)-Choice Scale in a Dutch Teacher Education Program. Asia-Pacific Journal of Teacher Education, 40, 249-269.

Gliem, J. A. \& Gliem, R. R. (2003) Calculating, Interpreting, and Reporting Cronbach's Alpha Reliability Coefficient for Likert-Type Scales, Midwest Research to Practice Conference in Adult, Continuing, and Community Education, Columbus, 2003.

Hays, J. (2018). Education in Vietnam | Facts and Details. Retrieved from http://factsanddetails.com/ southeast-asia/Vietnam/sub5_9f/entry-3457.html

Jugović, I., Marušić, I., Pavin Ivanec, T., \& Vizek Vidović, V. (2012). Motivation and personality of preservice teachers in Croatia. Asia-Pacific Journal of Teacher Education, 40, 271-287. doi: 10.1080/1359866x.2012.700044

Jung, J. (2014). Modeling the Occupational/ Career Decision-Making Processes of Intellectually Gifted Adolescents. Journal for the Education of the Gifted, 37, 128-152. doi: 10.1177/0162353214529045

Kılınç, A., Watt, H., \& Richardson, P. (2012). Factors Influencing Teaching Choice in Turkey. Asia-Pacific
Journal of Teacher Education, 40, 199-226. doi: 10.1080/1359866x.2012.700048

König,J.,\&Rothland,M.(2012).Motivations forchoosing teaching as a career: effects on general pedagogical knowledge during initial teacher education. AsiaPacific Journal of Teacher Education, 40, 289-315. doi: 10.1080/1359866x.2012.700045

Kyriacou, C., \& Coulthard, M. (2000). Undergraduates' Views of Teaching as a Career Choice. Journal of Education for Teaching, 26, 117-126. doi: 10.1080/02607470050127036

Kyriacou, C., Hultgren, Å., \& Stephens, P. (1999). Student teachers' motivation to become a secondary school teacher in England and Norway. Teacher Development, 3, 373-381. doi: 10.1080/13664539900200087

Lin, E., Shi, Q., Wang, J., Zhang, S., \& Hui, L. (2012). Initial motivations for teaching: comparison between preservice teachers in the United States and China. Asia-Pacific Journal of Teacher Education, 40, 227-248.

Low, E. L., Lim, S. K., Ch'ng, A., \& Goh, K. C. (2011). Pre-service teachers' reasons for choosing teaching as a career in Singapore. Asia Pacific Journal of Education, 31, 195-210.

McAleavy, T., Tran, T., \& Fitzpatrick, R. (2018). Promising Practice: Government Schools in Vietnam. Berkshire: Education Development Trust.

McKnight, K., Graybeal, L., Yarbro, J., \& Graybeal, J. (2016). Vietnam: What makes an effective teacher? [Ebook]. Pearson. Retrieved from https:// www.pearson.com/content/dam/one-dot-com/ one-dot-com/global/Files/efficacy-and-research/ schools/global-survey/summaries/RINVN9283 SummaryVietnam_092016.pdf

Pham, D. (2012). Forming Pedagogical Professional Value Orientation for Students in Normal Universities - Colleges in Current Time. Science Journal of University of Social Sciences and Humanities - Vietnam National University, $\mathrm{Ha}$ Noi, 28, 217-222.

Phan, Le Ha, \& Phan, Van Que (2006). Vietnamese Educational Morality and the Discursive Construction of English Language Teacher Identity. Journal of Multicultural Discourses, 1, 136-151. doi: 10.2167/md038.0

Richardson, P., Karabenick, S., \& Watt, H. (2014). Teacher Motivations: Theory and Practice (1st ed.). New York: Routledge.

Richardson, P., \& Watt, H. (2010). Current and future directions in teacher motivation research. Advances in Motivation and Achievement, 16B. doi: 10.1108/ S0749-7423(2010)000016B008

Tran, Le Huu Nghia (2015). Vietnamese Students' Perception of English Teacher Qualities: Implications 
for Teacher Professional Development. International Journal of Academic Research in Education and Review, 3, 7-19.

Watt, H., \& Richardson, P. (2007). Motivational Factors Influencing Teaching as a Career Choice: Development and Validation of the FIT-Choice Scale. The Journal of Experimental Education, 75, 167-202. doi: 10.3200/JEXE.75.3.167-202.

Watt, H., Richardson, P., Klusmann, U., Kunter, M., Beyer, B., Trautwein, U., \& Baumert, J. (2012). Motivations for choosing teaching as a career: An international comparison using the FIT-Choice scale. Teaching and Teacher Education, 28, 791805. doi: 10.1016/j.tate.2012.03.003.

Wigfield, A., \& Eccles, J. (2000). Expectancy-Value
Theory of Achievement Motivation. Contemporary Educational Psychology, 25, 68-81. doi: 10.1006/ ceps.1999.1015.

Yong, B. C. S. (1995). Teacher trainees' motives for entering into a teaching career in Brunei Darussalam. Teaching and Teacher Education, 11, 275-280.

Young, B. J. (1995). Career plans and work perceptions of preservice teachers. Teaching and Teacher Education, 11, 281-292.

Yu, Y., \& Bieger, G. (2013). Motivations for choosing a teaching career and deciding whether or not to teach in urban settings [Ebook]. Retrieved from http://jeten-online.org/index.php/jeten/article/ download/27/pdf

\title{
NGHIÊN CỬU VỀ ĐỘNG LỬC DẠY HỌC VÀ MỐI LIÊN Hệ VỚI Ý ĐỊNH THEO NGHỀ DẠY HỌC CỦA SINH VIÊN SU' PHẠM TIẾNG ANH
}

\author{
Trần Thị Hồng Duyên, Cao Thúy Hồng \\ Khoa Su phạm tiếng Anh, \\ Trường Đại học Ngoại ngũu, Đại học Quốc gia Hà Nội, \\ Phạm Văn Đồng, Cầu Giáy, Hà Nội, Việt Nam
}

Tóm tắt: Những năm gần đây, bên cạnh sự giảm về chất lượng và số lượng đầu vào của ngành đào tạo Sư phạm tiếng Anh, việc sinh viên ngành Sư phạm tiếng Anh sau khi tốt nghiệp làm trái ngành cũng đã khiến nhiều người phải suy ngẫm. Nghiên cứu này được thực hiện nhằm tìm hiểu động lực dạy của sinh viên năm cuối ngành Sư phạm tiếng Anh và mối quan hệ của động lực dạy và ý định theo đuổi nghề dạy học của sinh viên. Qua việc phân tích các dữ liệu định lượng thu được thông qua phiếu hỏi của 114 sinh viên năm cuối, nghiên cứu chỉ ra (a) các sinh viên sư phạm tiếng Anh tham gia nghiên cứu đều có ý định trở thành giáo viên sau khi tốt nghiệp, (b) trải nghiệm học tập, đóng góp cho xã họi và định huớng tương lai của trẻ em là những yếu tố ảnh hưởng nhiều đến động lực dạy học của các em, tuy nhiên (c) giáo viên - những người được yêu cầu có kiến thức chuyên môn và tận tâm với học trò - lại thường nhận mức lương thấp hơn mức cống hiến của họ, và (d) có mối quan hệ đáng chú ý giữa ý thức về giá trị nội tại của nghề, sự hài lòng với lựa chọn, ý thức về năng lực bản thân, và các kinh nghiệm dạy và học trước đây với ý định theo đuổi nghề dạy học.

Tù khóa: động lực dạy, ý định dạy, FIT-Choice, bối cảnh Việt Nam, giáo viên tương lai 


\section{APPENDIX 1}

Section A: Personal Information

1. Name:

2. Gender:

3. Age:

4. Class:

5. Email address:

Section B: Intention of Becoming a Teacher

Please respond to the following items on the scale from 1 (strongly disagree) to 7 (strongly agree) by circling the numbers that represent your choice.

\begin{tabular}{|l|l|l|l|l|l|l|l|l|}
\hline No. & \multicolumn{1}{|c|}{ Items } & & & & & & & \\
\hline 1 & I plan to apply for teaching career. & 1 & 2 & 3 & 4 & 5 & 6 & 7 \\
\hline 2 & I intend to pursue teaching career. & 1 & 2 & 3 & 4 & 5 & 6 & 7 \\
\hline 3 & I am committed to teaching career. & 1 & 2 & 3 & 4 & 5 & 6 & 7 \\
\hline 4 & It is likely that I will pursue teaching career. & 1 & 2 & 3 & 4 & 5 & 6 & 7 \\
\hline 5 & I have resolved to follow this occupational path. & 1 & 2 & 3 & 4 & 5 & 6 & 7 \\
\hline
\end{tabular}

\section{Section C: Motivations for Teaching}

To what extent do you agree or disagree with the following statements ( $1=$ strongly disagree; $7=$ strongly agree). Please circle an appropriate number.

\section{"I choose to become a teacher because..."}

\begin{tabular}{|l|l|l|l|l|l|l|l|l|}
\hline No. & \multicolumn{1}{|c|}{ Items } & & & & & & \\
\hline 1 & I am interested in teaching. & 1 & 2 & 3 & 4 & 5 & 6 & 7 \\
\hline 2 & Part-time teaching could allow more family time. & 1 & 2 & 3 & 4 & 5 & 6 & 7 \\
\hline 3 & My friends think I should become a teacher. & 1 & 2 & 3 & 4 & 5 & 6 & 7 \\
\hline 4 & As a teacher I will have lengthy holidays. & 1 & 2 & 3 & 4 & 5 & 6 & 7 \\
\hline 5 & I have the qualities of a good teacher. & 1 & 2 & 3 & 4 & 5 & 6 & 7 \\
\hline 6 & Teaching will allow me to provide a service to society. & 1 & 2 & 3 & 4 & 5 & 6 & 7 \\
\hline 7 & I have always wanted to be a teacher. & 1 & 2 & 3 & 4 & 5 & 6 & 7 \\
\hline 8 & $\begin{array}{l}\text { Teaching will be a useful job for me to have when } \\
\text { traveling. }\end{array}$ & 1 & 2 & 3 & 4 & 5 & 6 & 7 \\
\hline 9 & Teaching will allow me to shape child and adolescent values. & 1 & 2 & 3 & 4 & 5 & 6 & 7 \\
\hline 10 & I was unsure of what career I wanted. & 1 & 2 & 3 & 4 & 5 & 6 & 7 \\
\hline 11 & I like teaching. & 1 & 2 & 3 & 4 & 5 & 6 & 7 \\
\hline 12 & $\begin{array}{l}\text { I want a job that involves working with children and } \\
\text { adolescents. }\end{array}$ & 1 & 2 & 3 & 4 & 5 & 6 & 7 \\
\hline 13 & Teaching will offer a steady career path. & 1 & 2 & 3 & 4 & 5 & 6 & 7 \\
\hline 14 & Teaching hours will fit with the responsibilities of having a family. & 1 & 2 & 3 & 4 & 5 & 6 & 7 \\
\hline 15 & I have had inspirational teachers. & 1 & 2 & 3 & 4 & 5 & 6 & 7 \\
\hline 16 & As a teacher I will have a short workday. & 1 & 2 & 3 & 4 & 5 & 6 & 7 \\
\hline 17 & I have good teaching skills. & 1 & 2 & 3 & 4 & 5 & 6 & 7 \\
\hline 18 & Teachers make a worthwhile social contribution. & 1 & 2 & 3 & 4 & 5 & 6 & 7 \\
\hline 19 & Teaching qualification is recognized everywhere. & 1 & 2 & 3 & 4 & 5 & 6 & 7 \\
\hline 20 & Teaching will allow me to influence the next generation. & 1 & 2 & 3 & 4 & 5 & 6 & 7 \\
\hline 21 & My family thinks I should become a teacher. & 1 & 2 & 3 & 4 & 5 & 6 & 7 \\
\hline 22 & I want to work in a child and adolescent-centered environment. & 1 & 2 & 3 & 4 & 5 & 6 & 7 \\
\hline 23 & Teaching will provide a reliable income. & 1 & 2 & 3 & 4 & 5 & 6 & 7 \\
\hline 24 & School holidays will fit in with family commitments. & 1 & 2 & 3 & 4 & 5 & 6 & 7 \\
\hline
\end{tabular}




\begin{tabular}{|l|l|c|c|c|c|c|c|c|}
\hline 25 & $\begin{array}{l}\text { Teaching will allow me to have an impact on children and } \\
\text { adolescents. }\end{array}$ & 1 & 2 & 3 & 4 & 5 & 6 & 7 \\
\hline 26 & $\begin{array}{l}\text { Teaching will allow me to work against social } \\
\text { disadvantage. }\end{array}$ & 1 & 2 & 3 & 4 & 5 & 6 & 7 \\
\hline 27 & I have had good teachers as role models. & 1 & 2 & 3 & 4 & 5 & 6 & 7 \\
\hline 28 & Teaching enables me to give back to society. & 1 & 2 & 3 & 4 & 5 & 6 & 7 \\
\hline 29 & I was not accepted into my first-choice career. & 1 & 2 & 3 & 4 & 5 & 6 & 7 \\
\hline 30 & $\begin{array}{l}\text { Teaching will allow me to raise the ambitions of under- } \\
\text { privileged youth. }\end{array}$ & 1 & 2 & 3 & 4 & 5 & 6 & 7 \\
\hline 31 & I like working with children and adolescents. & 1 & 2 & 3 & 4 & 5 & 6 & 7 \\
\hline 32 & Teaching will be a secure job. & 1 & 2 & 3 & 4 & 5 & 6 & 7 \\
\hline 33 & I have had positive learning experiences. & 1 & 2 & 3 & 4 & 5 & 6 & 7 \\
\hline 34 & People I have worked with think I should become a teacher. & 1 & 2 & 3 & 4 & 5 & 6 & 7 \\
\hline 35 & Teaching is a career suited to my abilities. & 1 & 2 & 3 & 4 & 5 & 6 & 7 \\
\hline 36 & A teaching job will allow me to choose where I wish to live. & 1 & 2 & 3 & 4 & 5 & 6 & 7 \\
\hline 37 & I chose teaching as a last-resort career. & 1 & 2 & 3 & 4 & 5 & 6 & 7 \\
\hline 38 & $\begin{array}{l}\text { Teaching will allow me to benefit the socially } \\
\text { disadvantaged. }\end{array}$ & & & & & 7 \\
\hline
\end{tabular}

\section{Section D: Perceptions about Teaching}

Please respond to the following items on the scale from 1 (not at all) to 7 (extremely) by circling the numbers that represent your choice.

\begin{tabular}{|l|l|l|l|l|l|l|l|l|}
\hline No. & \multicolumn{1}{|c|}{ Items } & & & & & & & \\
\hline 1 & Do you think teaching is well paid? & 1 & 2 & 3 & 4 & 5 & 6 & 7 \\
\hline 2 & Do you think teachers have a heavy workload? & 1 & 2 & 3 & 4 & 5 & 6 & 7 \\
\hline 3 & Do you think teachers earn a good salary? & 1 & 2 & 3 & 4 & 5 & 6 & 7 \\
\hline 4 & Do you believe teachers are perceived as professionals? & 1 & 2 & 3 & 4 & 5 & 6 & 7 \\
\hline 5 & Do you think teachers have high morale? & 1 & 2 & 3 & 4 & 5 & 6 & 7 \\
\hline 6 & Do you think teaching is emotionally demanding? & 1 & 2 & 3 & 4 & 5 & 6 & 7 \\
\hline 7 & $\begin{array}{l}\text { Do you believe teaching is perceived as a high-status } \\
\text { occupation? }\end{array}$ & 1 & 2 & 3 & 4 & 5 & 6 & 7 \\
\hline 8 & Do you think teachers feel valued by the society? & 1 & 2 & 3 & 4 & 5 & 6 & 7 \\
\hline 9 & $\begin{array}{l}\text { Do you think teaching requires high levels of expert } \\
\text { knowledge? }\end{array}$ & 1 & 2 & 3 & 4 & 5 & 6 & 7 \\
\hline 10 & Do you think teaching is a hard work? & 1 & 2 & 3 & 4 & 5 & 6 & 7 \\
\hline 11 & Do you believe teaching is a well-respected career? & 1 & 2 & 3 & 4 & 5 & 6 & 7 \\
\hline 12 & Do you think teachers feel their occupation have high social status? & 1 & 2 & 3 & 4 & 5 & 6 & 7 \\
\hline 13 & $\begin{array}{l}\text { Do you think teachers need high levels of technical } \\
\text { knowledge? }\end{array}$ & 1 & 2 & 3 & 4 & 5 & 6 & 7 \\
\hline 14 & $\begin{array}{l}\text { Do you think that teachers need highly specialized } \\
\text { knowledge? }\end{array}$ & 1 & 2 & 3 & 4 & 5 & 6 & 7 \\
\hline 15 & How carefully have you thought about becoming a teacher? & 1 & 2 & 3 & 4 & 5 & 6 & 7 \\
\hline 16 & Were you encouraged to pursue careers other than teaching? & 1 & 2 & 3 & 4 & 5 & 6 & 7 \\
\hline 17 & $\begin{array}{l}\text { How satisfied are you with your choice of becoming a } \\
\text { teacher? }\end{array}$ & 1 & 2 & 3 & 4 & 5 & 6 & 7 \\
\hline 18 & Did others tell you teaching was not a good career choice? & 1 & 2 & 3 & 4 & 5 & 6 & 7 \\
\hline 19 & How happy are you with your decision of becoming a teacher? & 1 & 2 & 3 & 4 & 5 & 6 & 7 \\
\hline 20 & Did others influence you to consider careers other than teaching? & 1 & 2 & 3 & 4 & 5 & 6 & 7 \\
\hline
\end{tabular}

